\title{
Miconazole Nitrate
}

National Cancer Institute

\section{Source}

National Cancer Institute. Miconazole Nitrate. NCI Thesaurus. Code C29257.

The nitrate salt form of miconazole, an antifung al synthetic derivative of imidazole and used in the treatment of candidal skin infections, Miconazole selectively affects the integ rity of fungal cell membranes, high in ergosterol content and different in composition from mammalian cells membranes. ( $\mathrm{NCI04)}$ 